\begin{tabular}{|c|c|c|}
\hline ב & International Journal of Current Research in & \\
\hline & Biosciences and Plant Biology & \\
\hline $\begin{array}{l}\text { EXCELLENT } \\
\text { PUBLISHERS }\end{array}$ & $\begin{array}{c}\text { ISSN: 2349-8080 (Online) } \bullet \text { Volume } 3 \bullet \text { Number } 9 \text { (September-2016) } \\
\text { Journal homepage: } w \text { ww.ijcrbp.com }\end{array}$ & \\
\hline
\end{tabular}

\title{
Malting Barley Quality Parameters: Effect of Fertilization and Fungicide Application in the Argentine Pampas
}

\author{
Inés Cecilia Daverede ${ }^{*}$, Fernando Humberto Míguez ${ }^{2}$ and Juan Scanlan3 \\ ${ }^{1}$ Adjunct Professor and Researcher, Facultad de Ciencias Agrarias, Universidad Católica Argentina, Cap. Gral. R. Freire 183, \\ Ciudad de Buenos Aires, C1426AVC, Argentina \\ ${ }^{2}$ Professor and Senior Researcher, Facultad de Ciencias Agrarias, Universidad Católica Argentina, Cap. Gral. R. Freire 183, \\ Ciudad de Buenos Aires, C1426AVC, Argentina \\ 3Private Consultant. Cerfoly Argentina S.A. Conesa 251, Bragado, Provincia de Buenos Aires, CP 6640, Argentina
}

*Corresponding author.

\begin{abstract}
A b s t r a c t
The objective of this study was to evaluate the effect of nitrogen fertilization and fungicide application on yield, grain protein concentration and kernel plumpness on malting barley. Eleven experiments were replicated in Buenos Aires province, Argentina, during years 2012 and 2013. Treatments were: 1 . Control; $2.80 \mathrm{~kg} \mathrm{~N} \mathrm{ha}^{-1}$ applied at tillering; 3. treatment 2 plus a foliar application of $20 \mathrm{~kg} \mathrm{~N} \mathrm{ha}^{-1}$ at Z38; 4 . treatment 3 plus a foliar application of fungicide at Z38; and 5.treatment 4 plus a foliar application of fungicide at second detectable node. Nitrogen applied at tillering increased yields at the sites where soil $\mathrm{N}$ availability was below $100 \mathrm{~kg} \mathrm{~N} \mathrm{ha}^{-1}$, increased grain protein and decreased kernel plumpness on sites where kernel plumpness in the control plots was $<75 \%$. An extra foliar $\mathrm{N}$ fertilization did not affect yield or kernel plumpness, but increased grain protein concentration significantly 0.82 percentage points in $45 \%$ of the studied site-years. Fungicide application at Z38 increased yield and kernel plumpness in 2012, when high moisture conditions promoted fungal diseases. An extra fungicide application at second node stage had no consistent effect on the studied variables.
\end{abstract}

\section{Article Info}

Accepted: 06 August 2016

Available Online: 06 September 2016

\section{Keywords}

Fungal diseases

Hordeum vulgare

Mineral nutrition

Nitrogen

\section{Introduction}

Malting barley production has increased dramatically in Argentina in the last 10 years, expanding from its traditional area (southern Buenos Aires province) to new areas where growing conditions are different. Yield and kernel quality can be affected by location, tillage system, cropping sequence and other agronomic practices such as fertilization and disease control (O’Donovan et al., 2011; Sainju et al., 2013).

An efficient malting process requires that barley kernels meet certain parameters like a minimum germination capacity of $98 \%$ and no blending of cultivars. Grain protein concentration (GPC) and kernel plumpness (KP) are two of the most important traits required by the malting industry that can be modified through cultural practices. In Argentina, malting grade barley should have a GPC between 9\% and 13\%. In addition, the malting industry requires large and uniform kernels; at least $85 \%$ of kernels should be retained by a sieve with a $2.5 \mathrm{~mm}$ mesh and only up to $4 \%$ can be smaller than, and not be retained by a sieve with a $2.2 \mathrm{~mm}$ mesh. Farmers should meet the strict malting industry requirements to be able to sell theirs grain for malt production at a premium price; otherwise it is sold as 
livestock feed and the price is usually substantially lower.

Nitrogen $(\mathrm{N})$ fertilization is one of the most common cultural practices used to increase barley yield (Baethgen et al., 1995). Nitrogen applied to malting barley can also affect other properties of importance for the brewing process, including KP, enzyme activities, extractable malt, and diastatic power (Clancy et al., 1991; Therrien et al., 1994). Nitrogen fertilization usually increases yield, and this increase is mainly related to an increase in the number of kernels per unit area (Arisnabarreta and Miralles, 2008; Wamser and Mundstock, 2007).

The new kernels fixed by $\mathrm{N}$ fertilization usually come from spikelets in the distal part of the spike and/or from tillers; they tend to be smaller thus decreasing KP (Ellis and Marshall, 1998). The effect of $\mathrm{N}$ fertilization on GPC depends on the rate and timing of application, on the crop yield and on the variety seeded (O'Donovan et al., 2011). At very low soil $\mathrm{N}$ availability, $\mathrm{N}$ fertilization may increase yield without increasing or even slightly decreasing GPC, due to a dilution effect. As soil $\mathrm{N}$ availability increases, $\mathrm{N}$ fertilization may increase both yield and GPC; higher $\mathrm{N}$ fertilizer rates will produce smaller yield increases and will increase GPC. Any $\mathrm{N}$ fertilization application in excess of the maximum yield requirements may increase GPC over the accepted range and even cause lodging (Prystupa et al., 2004). Applications performed late in the growing season, from stem elongation to post-anthesis, may increase GPC as grain set may not increase, creating a greater $\mathrm{N}$ availability per kernel (Bulman and Smith 1993a, 1993b); $\mathrm{N}$ applied to younger tissues translocates more readily to grains than from older tissues (Matthiess et al., 2002). Somecultivars which were widely planted in Argentina (i.e. cv. Scarlett) tended to have very low GPC even with a relatively high $\mathrm{N}$ availability, while other older cultivars (i.e. cv. Quilmes Ayelen, Quimes Palomar) tended to increase GPC more readily with $\mathrm{N}$ application (Prystupa and Bergh, 2008). The same difference in response is found in modern cultivars. $\mathrm{N}$ fertilization should be managed carefully to increase yield without affecting malting barley commercial quality (Prystupa, 2005).

Several leaf diseases affect the barley crop in Argentina. The most important are barley rust (Puccinia hordei) and several leaf spots caused by fungi Drechslera teres, Bipolaris sorokiniana, Ramularia collocygni and Rynchosporium secalis (Carmona and Barreto, 1995;
Tomaso, 2004). Foliar diseases have been reported to reduce yields by up to $40 \%$ through a reduction in photosynthesis and/or by a change in the source/sink ratio (Khan, 1987; Jenkins et al., 1972). If infection occurs early in the growing season, grain set may be affected. Fungal infection later in the growing season will shorten the grain filling period, accelerate leaf senescence and change the source/sink ratio, thus limiting assimilate availability per kernel and decreasing KP (Carmona et al., 2011). Fungicide applications to control foliar diseases usually result in greater leaf green area duration at the grain filling stage, higher yields (Yang et al., 2000), increases in KP (Boatman, 1992; Conry and Dunne, 1993), and reductions in GPC due to the N dilution. Little is known on the relationship between the response of barley yield, GPC and KP to N application at tillering only or at tillering and flowering and the response to fungicide application at Z32 and Z38 or Z38.

The objective of this study was to evaluate the effect of soil and foliar $\mathrm{N}$ fertilization and fungicide application on yield, protein concentration and kernel plumpness of malting barley in several locations of the Argentine Pampas.

\section{Materials and methods}

Eleven experiments were replicated in Buenos Aires province, representing diverse agro-ecological environments of the Argentine Pampas, in years 2012 and 2013 (Table 1). Five treatments were established on $2 \times 5 \mathrm{~m}$ plots in a random complete blocks design (RCBD) with four replications and malting barley was sown from mid-June to mid-July at eleven sites. Three two-row cultivars were seeded; MP 1109 (one site), Andreia (seven sites) and an experimental cultivar C61 (four sites).

Before sowing, soil samples were taken at $0-0.20$ and0.20-0.40m depths; the former were analyzed for $\mathrm{pH}$ in water (Peech, 1965), organic carbon (Nelson and Sommers, 1982), extractable P [(extraction according to Bray and Kurtz (1945) and P quantification according to Murphy and Riley (1962)] and nitrate-N by micro distillation (Marbán, 2005), while 0.20-0.40 m-deep samples were only analyzed for nitrate-N (Table 1). Nitrate- $\mathrm{N}$ from $0.40-0.60 \mathrm{~m}$ was estimated as $50 \%$ of the nitrate- $\mathrm{N}$ from $0.20-0.40 \mathrm{~m}$, and the total contents $\left(\mathrm{kg} \mathrm{ha}^{-1}\right)$ of the three depths were added together.

Except for Chacabuco that was conventionally tilled before sowing with three disk-harrow passes, the rest of 
the sites were managed under no-tillage. Planting densities ranged from 230 to 330 plants $\mathrm{m}^{-2}$, the distance between rows was $0.175 \mathrm{~m}$. Triple superphosphate or di-ammonium phosphate were applied at planting at a rate of $20-30 \mathrm{~kg} \mathrm{P} \mathrm{ha}^{-1}$. The following treatments were applied after sowing: 1. Control; 2. $80 \mathrm{~kg} \mathrm{~N} \mathrm{ha}^{-1}$ applied at tillering (Z22, Zadoks et al., 1974); 3. $80 \mathrm{~kg} \mathrm{~N} \mathrm{ha}^{-1}$ at tillering (Z22) and a foliar application of $20 \mathrm{~kg} \mathrm{~N}^{-1}$ at the visible flag leaf stage (Z38); $4.80 \mathrm{~kg} \mathrm{~N} \mathrm{ha}^{-1}$ at tillering (Z22), a foliar application of fungicide plus $20 \mathrm{~kg} \mathrm{~N} \mathrm{ha}^{-1}$ at the visible flag leaf stage (Z38); $5.80 \mathrm{~kg} \mathrm{~N} \mathrm{ha}^{-1}$ at tillering (Z22), foliar application of fungicide at second detectable node (Z32) and a foliar application of fungicide plus $20 \mathrm{~kg} \mathrm{~N} \mathrm{ha}^{-1}$ at the visible flag leaf stage (Z38).

Treatments were selected on the basis of addition of technologies based on what farmers actually perform. A farmer who applies foliar $\mathrm{N}$ and an additional fungicide application in Z32 (before Z38) will most probably have fertilized his crop during tillering. Therefore, our treatments were chosen to keep the number of treatments to a minimum and to reflect the farmers' practices.

The $\mathrm{N}$ fertilizer urea (46-0-0) was broadcast at tillering, while the foliar fertilizer Foliarsol U (urea solution with low biuret, 20-0-0) was sprayed in an extra 1:1 dilution with water. In treatments 4 and 5 , Foliarsol $U$ was applied together with the fungicide AmistarXtra ${ }^{\circledR}$ (azoxystrobin + cyproconazole) at a rate of $400 \mathrm{ml} \mathrm{ha}^{-1}$.

Plants were hand-picked from the middle $2 \mathrm{~m}^{2}$ of each plot at crop maturity. Barley ears were threshed with an experimental thresher. Grain weight and GPC were corrected to $130 \mathrm{~g} \mathrm{~kg}^{-1}$ moisture (determined with a digital hygrometer). Kernel plumpness was calculated as percentage of grain weight retained by a sieve with a $2.5 \mathrm{~mm}$ mesh. Protein was determined by Near Infrared Reflectance (NIR) Spectroscopy.

Table 1. Relevant soil properties and rainfall at each experimental site and year in the province of Buenos Aires. The historical accumulated rainfall is the average total rainfall from June to December during the last 10 years.

\begin{tabular}{|c|c|c|c|c|c|c|c|}
\hline Year & Site & $\begin{array}{l}\mathrm{N}-\mathrm{NO}_{3}{ }_{3}^{-} \text {at } \\
\text { planting } \\
(0-60 \mathrm{~cm})\end{array}$ & $\begin{array}{l}\text { pH }(1: 2.5 \\
\text { soil:water) }\end{array}$ & OM & Bray P & $\begin{array}{l}\text { Accum. } \\
\text { Rainfall } \\
\text { Jun-Dec }\end{array}$ & $\begin{array}{l}\text { Historical } \\
\text { accum. rainfall }\end{array}$ \\
\hline & & $\mathrm{kg} \mathrm{ha}^{-1}$ & & $\%$ & $\mathrm{mg} \mathrm{kg}^{-1}$ & \multicolumn{2}{|c|}{----------- mm ----------- } \\
\hline 2012 & Carhué & 70 & 6.9 & 3.5 & 18 & 535 & 357 \\
\hline 2012 & Chacabuco & 105 & 6.1 & 3.6 & 5 & 818 & 498 \\
\hline 2012 & Chivilcoy 2 & 92 & 6.0 & 4.2 & 8 & 665 & 441 \\
\hline 2012 & Chivilcoy 1 & 138 & 6.1 & 4.2 & 33 & 665 & 441 \\
\hline 2012 & Junín 2 & 69 & 5.6 & 2.3 & 5 & 640 & 410 \\
\hline 2012 & Junín 1 & 69 & 5.6 & 2.3 & 5 & 640 & 410 \\
\hline 2012 & Pringles & 57 & 6.8 & 3.9 & 7 & 739 & 473 \\
\hline 2013 & Barrow & 53 & 5.8 & 4.6 & 17 & 306 & 398 \\
\hline 2013 & Bordenave & 212 & 6.4 & 2.0 & 34 & 236 & 336 \\
\hline 2013 & Bragado & 25 & 5.6 & 3.2 & 10 & 336 & 504 \\
\hline 2013 & San Antonio de Areco & 38 & 6.2 & 3.2 & 71 & 580 & 648 \\
\hline
\end{tabular}

A mixed model was used to analyze the effects of the $\mathrm{N}$ and fungicide treatments on yield, GPC and KP, using SAS 9.2 (SAS, 1992). Sites were nested within years, the site (year) combination was considered a fixed effect along with treatment, while blocks nested within sites were considered a random effect. The model accounted for heterogeneous variances across sites.

\section{Results and discussion}

Rainfall during the 2012 cropping season surpassed 54\% the historical average rainfall from tillering to physiological maturity (Table 1), causing high air humidity which created the conditions for a high incidence and severity of rust, net blotch, scald and ramularia. In contrast, rainfall for the same period during year 2013 was $24 \%$ below the historical average and the incidence and severity of the same diseases was insignificant. In central Buenos Aires (near Bragado), mean and minimum temperatures between August and November 2012 were approximately $1.5^{\circ} \mathrm{C}$ and $2.1^{\circ} \mathrm{C}$ higher than during 2013 , possibly increasing fungi incidence along with the higher rainfall. However, maximum temperatures were $2.5^{\circ} \mathrm{C}$ higher during those months and in December in 2013 (Table 2). 
Table 2. Mean, minimum, maximum and daylight hours during 2012 and 2013 near Bragado, center of Buenos Aires province.

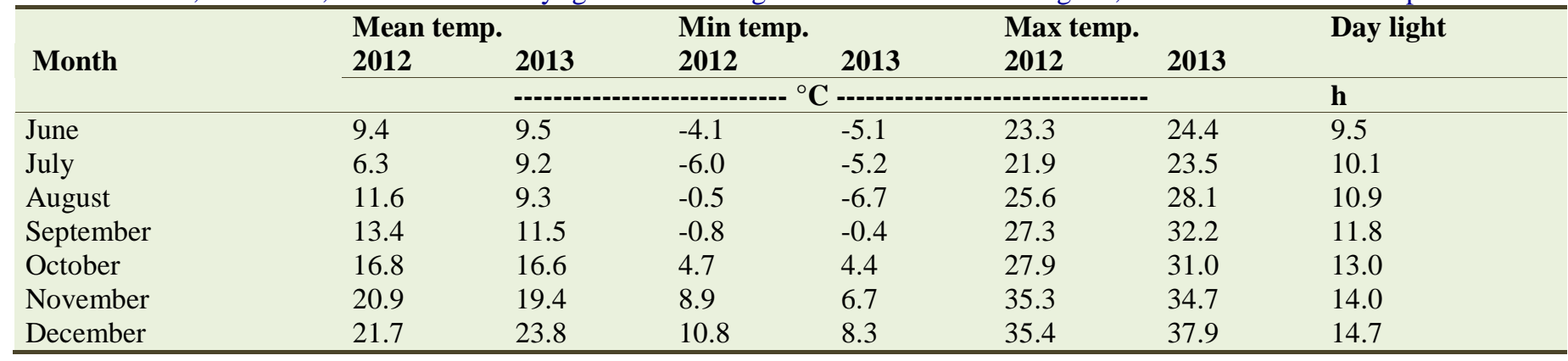

The interaction treatment $\times$ site (year) was significant for yield, GPC and KP $(p<0.01)$, meaning that the response in yield, GPC and KP to fertilization and fungicide application differed among site-years.

\section{Yield, protein and kernel plumpness response to $\mathrm{N}$ fertilization at tillering}

Malting barley yields ranged from 1439 to $6310 \mathrm{~kg} \mathrm{ha}^{-1}$, averaging $3571 \mathrm{~kg} \mathrm{ha}^{-1}$. The application of $80 \mathrm{~kg} \mathrm{~N} \mathrm{ha}^{-1}$ at tillering increased yields significantly $(p<0.1)$ in 8 out of 11 site-years ( $73 \%$ of the studied site-years) by an average of $677 \mathrm{~kg} \mathrm{ha}^{-1}$. There was an inverse relationship between yield response to $\mathrm{N}$ fertilization at tillering and $\mathrm{N}$ soil availability at planting (Fig. 1). Yield response to $\mathrm{N}$ fertilization at tillering was not associated to other soil variables such as available soil $\mathrm{P}, \mathrm{pH}$ or $\mathrm{OM}$.

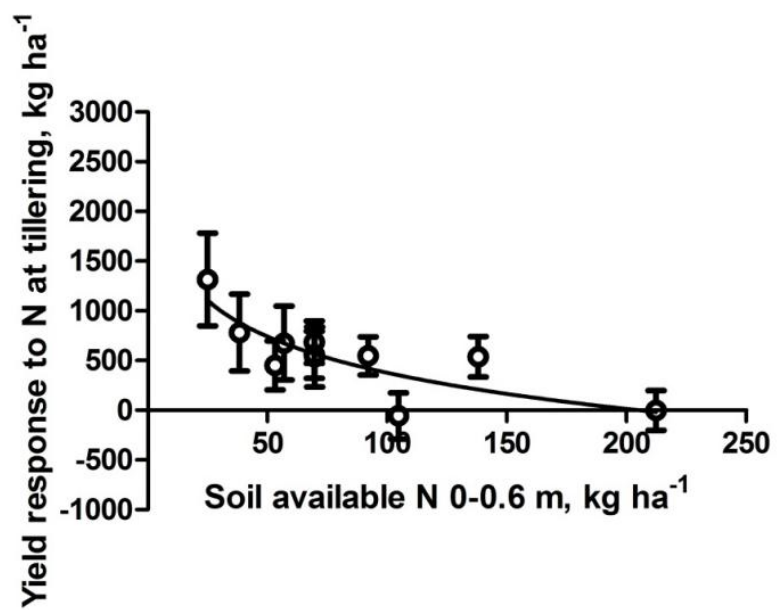

Fig. 1: Malting barley yield response $\left(\mathrm{kg} \mathrm{ha}^{-1}\right)$ to the application of $80 \mathrm{~kg} \mathrm{~N}^{-1}$ at tillering as a function of soil available $\mathrm{N}\left(\mathrm{NO}_{3}-\mathrm{N} 0-0.60 \mathrm{~m}\right)$ at sowing for 11 sites in the province of Buenos Aires, Argentina. Each point represents the average value of four repetitions per site while bars indicate the standard error of the mean. $Y=2791-524 * \ln (x)$.

Protein percentage averaged 11.4, ranging from 8.6 to $15 \%$ for all treatments. Nitrogen applied at tillering increased GPC by an average 1.25 percentage points in 4 site-years $(36 \%$ of the studied site-years; $p<0.1)$. Soil available $\mathrm{N}$, considered as the sum of nitrate- $\mathrm{N}$ at planting + fertilizer $\mathrm{N}$, was linearly related to protein kernel percentage $\left(p<0.001 ; \mathrm{R}^{2}=0.3\right)$. An increase in 50 $\mathrm{kg} \mathrm{N} \mathrm{Na}^{-1}$ of available $\mathrm{N}$ (through soil $\mathrm{N}$ or fertilization) would increase the protein percentage in approximately half a percentage point. When years were analyzed separately, two regression lines were fitted which differed in their y-intercept but not in the slopes. Protein was therefore 1.77 percentage points greater for year 2013 than for year 2012, but the protein increase per increase in available $\mathrm{N}$ did not differ significantly $(p=0.22)$ between years (data not shown).

Year 2012 could have lower GPC compared to 2013 due to the excessive rainfall from tillering to grain set which caused low radiation and severe foliar diseases, decreasing photosynthesis and thus lowering yields. On the other hand, in 2012, the excessive rainfall may have percolated nitrates outside the soil volume explored by roots.

Considering all the data points, there was no relationship between yield and GPC. When GPC was related to N availability per $\mathrm{Mg}$ of grain yield according to McKenzie et al. (2004), a positive relationship was found with a low $\mathrm{R}^{2}$ (0.11). When each year was considered separately, the fit increased significantly (Fig. 2), just as with GPC as a function of available N. However, the inclusion of yield increased the fit for the model for year 2012 , increasing from 0.3 to 0.52 .

According to the equation obtained for $2013,37.1 \mathrm{~kg} \mathrm{~N}$ are needed per $\mathrm{Mg}$ of yield to reach $12 \%$ GPC, while for 2012, $106.4 \mathrm{~kg} \mathrm{~N} \mathrm{Mg}^{-1}$ were needed to reach the same GPC. The equation derived from year 2013 (Fig. 3), which is more representative of historical rainfall averages, could be useful to estimate the rate of $\mathrm{N}$ fertilization needed to obtain a given GPC, when the target yield is estimated, but if environmental conditions 
substantially affect the obtained yield, its predictability is reduced. Magliano et al. (2014) found a lower Yintercept (7.267) and a higher slope (0.08) when relating $\mathrm{N}$ availability per $\mathrm{Mg}$ of grain yield. This was probably due to the use of Scarlett variety, which tends to have lower GPC compared to more modern varieties, and to different environmental conditions during grain fill.

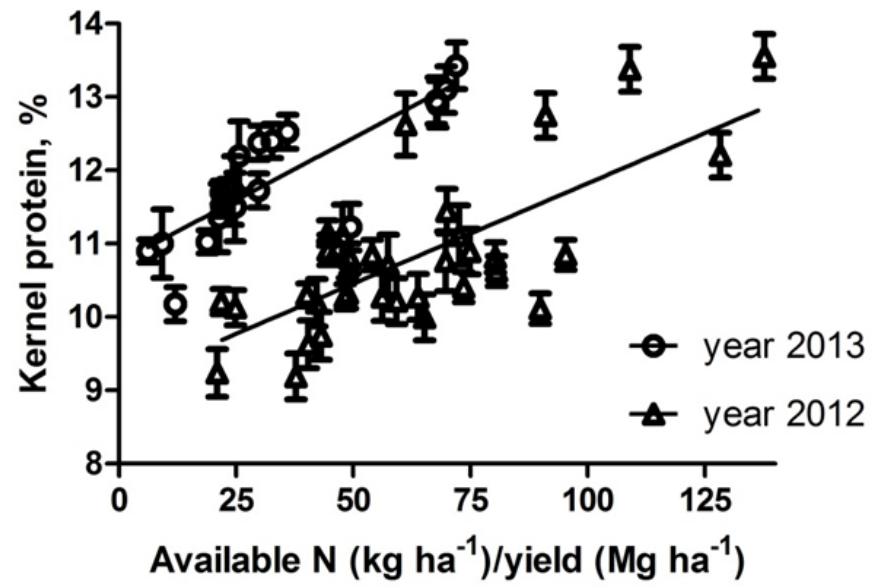

Fig. 2: Malting barley kernel protein percentage as a function of available $\mathrm{N}$ yield ${ }^{-1}$ for all studied sites. Each data point represents a particular treatment and is the average of 4 repetitions (vertical bars denote standard errors) in 11 sites throughout the province of Buenos Aires. Year 2013: $\mathrm{Y}=10.74+0.034 \mathrm{x}, \mathrm{R}^{2}=.70$; Year 2012: 9.088+0.02736 $\mathrm{x}$, $\mathrm{R}^{2}=.52$. Slopes do not differ significantly between models $(p=0.42)$ while $\mathrm{Y}$-intercepts do $(p<0.0001)$.

Malting barley KP above the $2.5 \mathrm{~mm}$ mesh ranged from 270 to $980 \mathrm{~g} \mathrm{~kg}^{-1}$, averaging $784 \mathrm{~g} \mathrm{~kg}^{-1}$ throughout all site-years. Nitrogen application at tillering decreased KP significantly by 8.6 percentage points in 8 out of 11 siteyears $(73 \%$ of site-years; $p=0.11)$. In only five sites, the non-fertilized plots produced kernels that complied with the $850 \mathrm{~g} \mathrm{~kg}^{-1}$ minimum KP required by the industry. Nitrogen fertilization on these sites without fungicide application further decreased these values, placing $75 \%$ of the sites below the malting industry minimum requirement.

The decrease in KP produced by $\mathrm{N}$ application at tillering was more pronounced on sites that had low KP without fertilization (Fig. 3); similar results were reported by O’Donovan et al. (2011). This was probably due to an increased grain set in distal spikelets and in spikes from tillers when $\mathrm{N}$ was applied at tillering, increasing grain number and decreasing the source/sink relationship. In addition, smaller grains tend to have a higher GPC than larger kernels (Prystupa and Ferraris, 2011; Magliano et al., 2014).

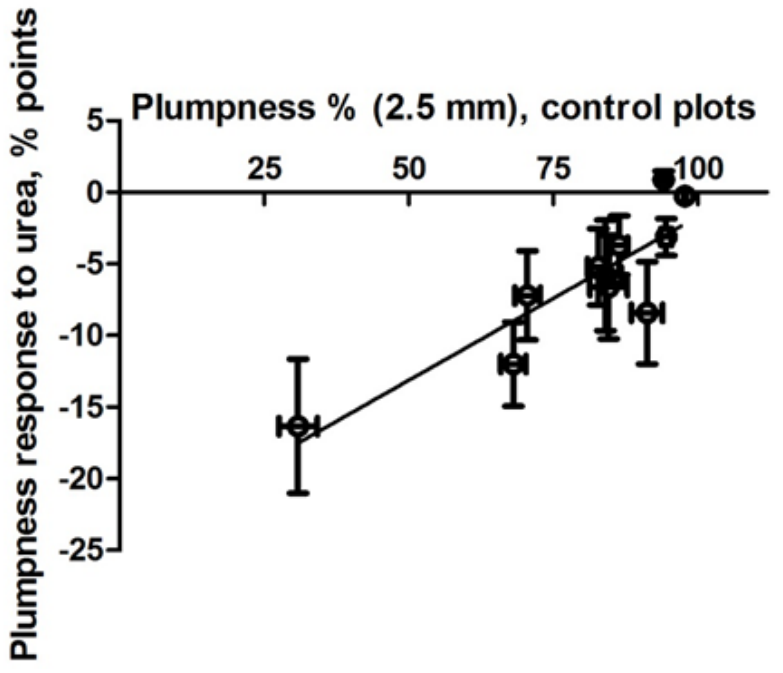

Fig. 3: Malting barley plumpness response (percentage points) to $80 \mathrm{~kg} \mathrm{~N} \mathrm{ha}^{-1}$ applied at tillering as a function of plumpness percentage in control plots for all studied sites. Each point represents the average value of four repetitions per site while horizontal and vertical bars indicate the standard error of the mean. $\mathrm{Y}=-24.57+0.2288 \mathrm{x}, \mathrm{R}^{2}=0.77$.

There was a slight but non-significant positive correlation $(\mathrm{r}=0.47 ; p<0.15)$ between $\mathrm{KP}$ and grain yield in the control treatments (data not shown), suggesting that kernel size was a significant component of yield only in some site-years.

Yield, protein and plumpness response to Foliar $\mathbf{N}$ application in $\mathbf{Z 3 8}$ in addition to $\mathbf{N}$ application at tillering (treatment 3 vs. 2)

Yield was not affected by an extra $\mathrm{N}$ foliar fertilization at Z38 at any site-year, while it increased protein percentage in 5 out of 11 site-years ( $45 \%$ of the site-years) by an average 0.82 percentage points $(p<0.05)$. When the application of foliar $\mathrm{N}$ fertilization plus $\mathrm{N}$ at tillering was compared with the control (treatments 3 vs 1 ) it increased GPC in 7 out of 11 site-years (64\% of studied site-years) by an average 1.5 percentage points $(p<0.1)$, all three cultivars responded in a similar way to $\mathrm{N}$ fertilization regarding GPC. Míguez et al. (2013) analyzed several N fertilization experiments in wheat and concluded that foliar $\mathrm{N}$ fertilization increased GPC when a high $\mathrm{N}$ rate was applied at anthesis. Kernel plumpness was not consistently affected by foliar $\mathrm{N}$ application; it increased in two sites but decreased in two others $(p<0.1)$.

Yield, protein and plumpness response to fungicide application in Z38 (treatment 4 vs. 3)

Yield was not affected by fungicide application in 2013 
since foliar disease incidence was insignificant. In 2012, 5 out of 7 sites $(71 \%)$ responded to fungicide application by an average $516 \mathrm{~kg} \mathrm{ha}^{-1}(\mathrm{P}<0.11)$. This could be explained by differences in environmental conditions and foliar diseases incidence among site-years. In the presence of scald (Rhynchosporium secalis), Boatman (1992) found that fungicides applied between flag leaf sheath extension and first spikelet of inflorescence just visible increased the green lamina area of the flag leaf and second leaf at the late milk stage of grain development, significantly increasing barley 1000-grain weight, directly associated to KP, and also increasing yields in up to $680 \mathrm{~kg} \mathrm{ha}^{-1}$.

There was not a consistent effect of fungicide application on GPC since it only affected one site negatively and one site positively (averaging -0.5 and 1.5 percentage point, respectively; $p<0.1)$.

Fungicide application at Z38 in 2012 compensated the decrease in KP caused by $\mathrm{N}$ application at tillering. Fungicide application only partly reversed the decrease in $\mathrm{KP}$ caused by $\mathrm{N}$ fertilization at tillering in one site, while it was completely reversed in the rest of the sites, since KP was not significantly different from the control treatment. For that year, in 6 out of 7 sites, where foliar diseases incidence was greater, fungicide application at Z38 increased KP by 10.9 percentage points (treatment 4 vs. 3). In 2013, fungicide application increased KP significantly $(p<0.1)$ in only one site in 3.2 percentage points. Four sites in 2012 and two sites in 2013 did not meet the $85 \%$ plumpness required by the industry albeit receiving a fungicide application in Z38 in addition to urea and foliar $\mathrm{N}$.

When both fungicide treatments were contrasted to both fertilization treatments without fungicide (treatments $4+5$ vs. $2+3), \mathrm{KP}$ increased in 9 out of 11 site-years $(82 \%$ of all site-years) with fungicide applications, and the average increase was 8.3 percentage points $(p<0.1)$.

For all site-years, the increase in KP due to fungicide treatments was greater when the average KP of the site was lower (Fig. 4A). This could be due to a smaller effect when kernels size is greater, and close to its potential size, than when they are smaller, since the main effect of fungicides is to increase the source strength during grain fill by controlling foliar diseases. Also, fungicide effect on KP was greater when the control yields at each site were lower, probably associated with the relationship between yield and KP (Fig. 4B).
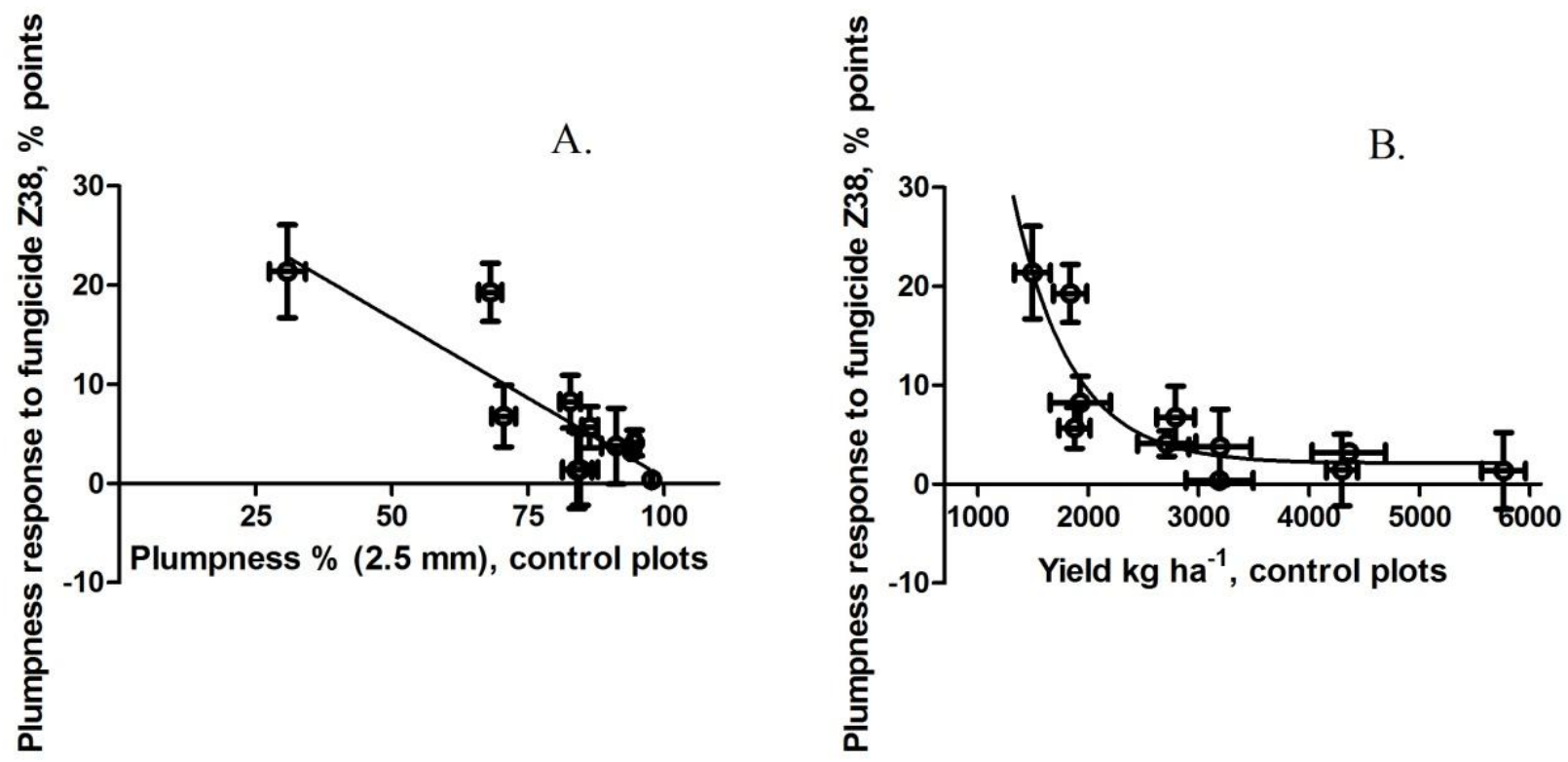

Fig. 4: Malting barley kernel plumpness $(>2.5 \mathrm{~mm})$ response (percentage points) to fungicide applied at Z38 as a function of kernel plumpness in un-treated plots (controls; A.) and as a function of yield in un-treated plots (B.) at 11 sites throughout the province of Buenos Aires. Each point represents the average value of four repetitions per site while horizontal and vertical bars indicate the standard error of the mean. A. $\mathrm{Y}=32.78-0.322 \mathrm{x}\left(p<0.01 ; \mathrm{R}^{2}=0.74\right)$. B.Y= $(339.5-2.107) * \exp (-0.001911 * x)+2.107$. 
The positive effect of fungicide on kernel plumpness was greater on plots where $\mathrm{N}$ applied at tillering decreased plumpness to a greater extent (Fig. 5).

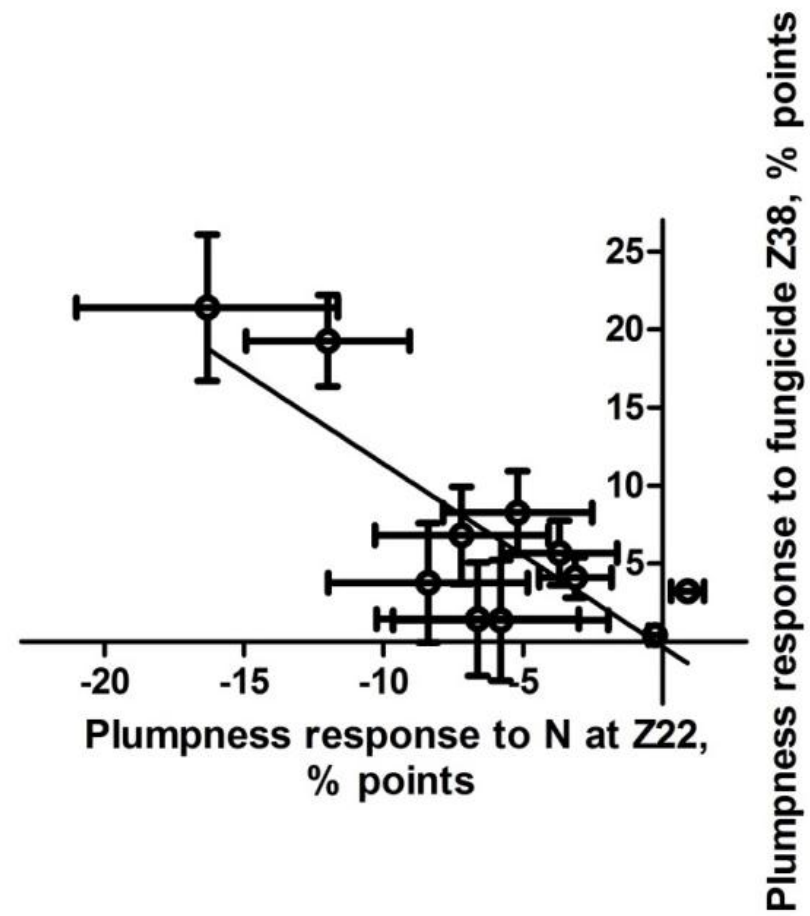

Fig. 5: Malting barley kernel plumpness response to fungicide application at $\mathrm{Z} 38$ as a function of kernel plumpness response to $80 \mathrm{~kg} \mathrm{~N} \mathrm{ha}^{-1}$ application at tillering. Each point represents the average value of four repetitions per site while horizontal and vertical bars indicate the standard error of the mean. $\mathrm{Y}=-0.3339-1.171 \mathrm{x} \quad(p<0.0002$; $\left.\mathrm{R}^{2}=0.67\right)$.

Yield, protein and plumpness response to an additional fungicide application in $\mathrm{Z32}$ vs. a sole application at Z38 (treatment 5 vs. 4)

An extra application of fungicide at Z32 (second node detectable) had no consistent effecton yield andthe latter decreased significantly by $780 \mathrm{~kg} \mathrm{ha}^{-1}$ in only one site $(p<0.1)$. In addition, the extra fungicide application decreased GPC in 1.14 percentage points in 3 out of 11 site-years $(27 \%$ of studied site-years $p<0.1)$. Kernel plumpness was not affected by an extra fungicide application in Z32. These results agree with those observed by Turkington et al. (2015), whom conducted split applications of fungicide at the time of herbicide application (tillering; earlier than in our study) and at flag leaf emergence and concluded that the split applications did not improve disease management and crop productivity compared with a single full rate fungicide application at the flag leaf stage.

\section{Conclusion}

In the Argentine Pampas region, $\mathrm{N}$ fertilization at tillering increased malting barley yields when soil available $\mathrm{N}$ was smaller than $100 \mathrm{~kg} \mathrm{~N} \mathrm{ha}^{-1}$. No matter what content of soil available $\mathrm{N}, \mathrm{N}$ fertilization at this stage produced GPC increases and KP decreases, especially in control plots with low KP percentages. Nitrogen fertilization at Z38 was an effective management practice to increase GPC without affecting yield or KP. Fungicide applications before anthesis increased yields and KP only under environmental conditions that promoted foliar diseases. An extra fungicide application at Z32 had no consistent effect on yield, GPC or KP.

\section{Conflict of interest statement}

Authors declare that they have no conflict of interest.

\section{Acknowledgement}

To the students of Facultad de Ciencias AgrariasUniversidad Católica Argentina who conducted the field work: Santiago Aprile, Matías Lerda, Nicolás Lopez, Juan Francisco Marini, Francisco Raimondi, Bernardo Moreno, Mariano Romero, Rafael Velilla, Rodrigo Martinez, Nicolas Cámpora, Danilo Marini, Gregorio Gasparini and Matías Capellades. Fertilizers were provided by Bunge de Argentina S.A. and fungicides by BASF Argentina S. A. We are grateful to researchers Antonio Hall and Pablo Prystupa for their valuable comments and suggestions.

\section{References}

Arisnabarreta, S., Miralles, D. J., 2008. Critical period for grain number establishment of near isogenic lines of two- and six-rowed barley. Field Crops Res. 107(3), 196202.

Baethgen, W.T., Christianson, C. B., Garcia Lamothe, A., 1995. Nitrogen fertilizer effects on growth, grain yield, and yield components of malting barley. Field Crops Res. 43(2-3), 87-89.

Boatman, N.D., 1992. Effects of herbicide use, fungicide use and position in the field on the yield and yield components of spring barley. J. Agric. Sci. 118, 17-28.

Bray, R. H., Kurtz, L.T., 1945. Determination of total, organic and available forms of phosphorus in soil. Soil Sci. 59(1), 39-45.

Bulman, P., Smith, D.L., 1993a. Grain protein response of spring barley to high rates and post-anthesis application of fertilizer nitrogen. Agron. J. 85(6), 1109-1113. 
Bulman, P., Smith, D.L., 1993b. Yield and yield component response of spring barley to fertilizer nitrogen. Agron. J. 85(2), 226-231.

Carmona, M. A., Barreto, D. E., 1995. Enfermedades fúngicas de la cebada cervecera en la provincia de Buenos Aires (Argentina). Fitopat. Bras. 20, 509-510.

Carmona, M. A., Barreto, D., Romero, A. M., 2011. Enfermedades del cultivo. importancia, síntomas y manejo integrado. Cebada cervecera. (Eds.: Miralles, D., BenechArnold, R., Albedo, G.). Buenos Aires, Editorial Facultad de Agronomía, Universidad de Buenos Aires. pp.133-169.

Clancy, J.A., Tillman, B.A., Pan, W.L., Ullrich, S.E., 1991. Nitrogen effects on yield and malting quality of barley genotypes under no till. Agron. J. 83(2), 341-346.

Conry, M.J., Dunne, B., 1993. Effects of nitrogen timing and frequency of fungicide applications on grain yields of winter barley in Ireland. J. Agric. Sci. 120(2), 181-186.

Ellis, R.P., Marshall, B., 1998. Growth, yield and grain quality of barley (Hordeum vulgare L.) in response to nitrogen uptake: Plant development and rate of germination. J. Exp. Bot. 49(323), 1021-1029.

Jenkins, J. E. E., Melville, S. C., Jemmett, J. L., 1972. The effect of fungicides on leaf diseases and on yield in spring barley in South-west England. Plant Path. 21(2), 49-58.

Khan, T.N., 1987. Relationship between net blotch (Drechslera teres) and losses in grain yield of barley in Western Australia. Aust. J. Agric. Res. 38(4), 671-679.

Lauer, J.G., Partridge, J. R., 1990. Planting date and nitrogen rate effects on spring malting barley. Agron. J. 82(6), 1083-1088.

Magliano, P.N, Prystupa, P., Gutiérrez Boem, F.H., 2014. Protein content of grains of different size fractions in malting barley. J. Inst. Brewing. 120(4), 347-352.

Marbán, L., 2005. Métodos de extracción y determinación de nitratos en suelos. Part (II). In: Tecnologías en análisis de suelos. (Eds.: Marbán, L., Ratto, S.). Asociación Argentina de la Ciencia del Suelo (AACS). pp.131-138.

Matthiess, W., Serre, M., Cattaneo, M., 2002. Fertilización nitrogenada en una variedad de cebada cervecera de alto potencial de rendimiento en la Argentina. Proceedings XXII Reunião Anual de Pesquisa de Cevada. Passo Fundo, Brasil, 9-11.

McKenzie, R.H., Middleton, A.B., Hall, L., DeMulder, J., Bremer, E., 2004. Fertilizer response of barley grain in Southern and Central Alberta. Can. J. Soil Sci. 84(4), 513523.

Míguez, F.H., Pérez, A. A., Fresco, J. A., Zapiola, M. L., 2013. Meta-analysis of nitrogen fertilization effects of wheat grain protein in Argentina. Open Sci. Repos. Agric. e70081981.

Murphy, J., Riley, H. P.1962. A modified single solution method for the determination of phosphate in natural waters. Anal. Chim. Acta. 27, 31-36.
Nelson, D.W., Sommers, E., 1982. Total carbon, organic carbon and organic matter. In: Methods of Soil Analysis (Ed.: Page, A.L.). Part 2. $2^{\text {nd }}$ Edn. Agronomy. 9, 534-579.

O’Donovan, J.T., Turkington, T.K.,Edney, M.J., Clayton, G.W., McKenzie, R. H., Juskiw, P. E.,Lafond, G.P, Grant, C.A., Brandt, S., Harker, K.N., Johnson, E.N., May W. E., 2011. Seeding rate, nitrogen rate, and cultivar effects on malting barley production. Agron. J. 103(3), 709-716.

Peech, M., 1965. Method for soil pH in water: Hydrogen-ion activity. In: Method of Soil Analysis. Part II. Chemical and Microbiological Properties (Ed.: Black, C.A.). American Society of Agronomy, Madison, WI. pp.915-926.

Prystupa, P., Bergh, R., 2008. Fertilización de cebada cervecera. W. Scarlett. IV. Estimación de la respuesta del contenido proteico a la fertilización nitrogenada. XXI Congreso Argentino de Ciencias del Suelo. Potrero de Funes, Pcia. de San Luis. 239p.

Prystupa, P., Ferraris, G., 2011. Nutrición mineral y fertilización. En: Cebada cervecera. (Eds.: Miralles, D.J., Benech Arnold, R.L., Abeledo, L.G.). Editorial Facultad de Agronomía. Buenos Aires. pp.35-62.

Prystupa, P., Savin, R., Slafer, G. A., 2004. Grain number and its relationship with dry matter, $\mathrm{N}$ and $\mathrm{P}$ in the spikes at heading in response to NP fertilization in barley. Field Crops Res. 90(2-3), 245-254.

Prystupa, P., 2005. Cebada y Avena. In: Fertilidad de Suelos y Fertilización de Cultivos (Eds.: Echeverría, H., García, F.). Ediciones INTA. Buenos Aires, Argentina. pp.317-334.

Sainju, U.M., Lenssen, A.W., Barsotti, J.L., 2013. Dryland malt barley yield and quality affected by tillage, cropping sequence, and nitrogen fertilization. Agron. J. 105(2), 329-340.

Therrien, M.C., Grant, C.A., Carmichael, C.A., Noll, J.S., 1994. Effect of fertilizer management, genotype, and environmental factors on some malting quality characteristics in barley. Can. J. Plant Sci. 74(3), 545-547.

Tomaso, J. C., 2004. Cebada cervecera en la Argentina. IDIA XXI. 4(6), 210-216.

Turkington, T. K., O'Donovan, J. T., Harker, K. N., Xi, K., Blackshaw, R. E., Johnson, E. N., Stevenson, C., 2015. The impact of fungicide and herbicide timing on foliar disease severity, and barley productivity and quality. Can. J. Plant Sci. 95(3), 525-537.

Wamser, A. F., Mundstock, C. M., 2007. Nitrogen fertilization at different growth stages in barley, cultivar 'MN698'. Ciência Rural. 37(4), 942-948.

Yang, J.P., Sieling, K., Hanus, H., 2000. Effects of fungicide on grain yield of barley grown in different cropping systems. J. Agric. Crop Sci. 185(3), 153-162.

Zadoks, J.C., Chang T.T., Konzak, C. F., 1974. A decimal code for the growth stages of cereals. Weed Res. 14, 415-421.

\section{How to cite this article:}

Daverede, I. C., Míguez, F. H., Scanlan, J., 2016. Malting barley quality parameters: Effect of fertilization and fungicide application in the Argentine Pampas. Int. J. Curr. Res. Biosci. Plant Biol. 3(9), 1-8. doi: http://dx.doi.org/10.20546/ijcrbp.2016.309.001 